\title{
The ecological integrity of the Lower Olifants River, Limpopo province, South Africa: 2009-2015 - Part A: Olifants River main stem
}

\section{SM Marr, TD Mohlala \& A Swemmer}

To cite this article: SM Marr, TD Mohlala \& A Swemmer (2017) The ecological integrity of the Lower Olifants River, Limpopo province, South Africa: 2009-2015 - Part A: Olifants River main stem, African Journal of Aquatic Science, 42:2, 171-179, DOI: 10.2989/16085914.2017.1334501

To link to this article: http://dx.doi.org/10.2989/16085914.2017.1334501

+ View supplementary material

Submit your article to this journal $\pi$

View related articles 주

Citing articles: 1 View citing articles $\asymp$
Published online: 24 Aug 2017. 


\title{
The ecological integrity of the Lower Olifants River, Limpopo province, South Africa: 2009-2015 - Part A: Olifants River main stem
}

\author{
SM Marr ${ }^{1,2}$, TD Mohlala ${ }^{3}$ and A Swemmer ${ }^{3 *}$ \\ 1 South African Institute for Aquatic Biodiversity, Grahamstown, 6140, South Africa \\ ${ }^{2}$ Centre for Invasion Biology, South African Institute for Aquatic Biodiversity, Grahamstown, 6140, South Africa \\ 3 SAEON Ndlovu Node, Kruger National Park, Phalaborwa, 1390, South Africa \\ * Corresponding author, e-mail: tony@saeon.ac.za
}

\begin{abstract}
The major rivers of the South African 'Lowveld' (low-latitude savanna) suffer numerous impacts from upstream economic activities. Whereas monitoring these rivers is required to detect biodiversity losses, record pollution events and devise mitigation strategies, current monitoring programmes are inadequate. In 2009, the South African Earth Observation Network initiated an intensive long-term research programme on the Lowveld reaches of the Olifants River. Physico-chemical parameters, aquatic macroinvertebrates and fish abundances were recorded at four Lowveld sites in the Olifants River. We review six years of this programme. The results suggest deterioration in the ecological condition of the Olifants River with no discernible improvement through protected areas. Trends could not be detected. The parameters measured, sampling methods and/or sampling frequency might be responsible for the limited trends observed, or alternatively the results simply reflect stable conditions despite on-going pollution. Real time monitoring and an expansion in the parameters monitored would add value to the monitoring programme.
\end{abstract}

Keywords: aquatic macroinvertebrates, freshwater fish, long-term biomonitoring, Lowveld, river health, water quality

Online Supplementary Material: Table S1: List of aquatic invertebrate taxa recorded at each site over the period of the study and Table S2: List of fish species recorded at each site over the sampling period, available at http://dx.doi.org/10.2989/16085914.2017.1334501

Introduction

Freshwater ecosystems are the most threatened ecosystems in the world (Bunn 2016) with overabstraction and impounding, or contaminants caused by, inter alia, increases in mining, agricultural, industrial and domestic water use, threatening many river systems globally (Vörösmarty et al. 2010) and in South Africa (Ashton and Dabrowski 2011). The rivers of the Lowveld aquatic ecoregion of South Africa, sensu Kleynhans et al. (2005), are widely regarded as some of South Africa's most degraded river systems (Nel et al. 2007). Reduced water flows, high sediment loads, regular discharges of raw sewage, elevated nutrient levels and mobilization of metals have been reported for all perennial rivers of the ecoregion. Pressures driving this degradation are likely to increase with new dams and mines under construction or planned, domestic, industrial and agricultural demands for fresh water increasing and many water treatments facilities operating beyond maximum capacity (Ashton and Dabrowski 2011). The decline in the Lowveld's rivers poses a threat to sustainable economic development in the region. Such trends, if left unchecked, are disturbing because in the long-term, the water quality for human consumption and irrigation is ultimately declining, whereas reductions in ecotourism revenues could occur as a result of degradation of riparian and aquatic ecosystems in the Kruger
National Park and its neighbouring private game reserves, in addition to possible impacts on downstream water users in Mozambique.

The Olifants River, a tributary of the Limpopo River in eastern South Africa (Figure 1), is one of the largest rivers traversing the Kruger National Park, but is now one of the most polluted river systems in South Africa (Heath et al. 2010; Ashton and Dabrowski 2011). The annual median sulphate concentration, an indication of the impact of acid mine drainage in the catchment (de Villiers and Mkwelo 2009), has increased at a rate of 2.76 $\mathrm{mg} \mathrm{l}^{-1}$ per year at Loskop Dam over the past five decades (Jooste et al. 2015) and it is now approaching the $200 \mathrm{mg}$ $\mathrm{I}^{-1}$ threshold for human consumption (Jooste et al. 2015). Although diluted by tributaries, the median sulphate concentration is nevertheless increasing at a rate of 0.59 $\mathrm{mg} / \mathrm{L}$ per annum at the Phalaborwa Barrage, approximately $400 \mathrm{~km}$ downstream of Loskop Dam (Jooste et al. 2015). There is therefore growing concern regarding the long-term impact of water pollution on the human populations and aquatic ecosystems of the Olifants River and its tributaries in the Lowveld, the Kruger National Park and Mozambique.

This means that since the Resource Quality Objectives have desired state for the lower Olifants River to be $\mathrm{C}$ or 


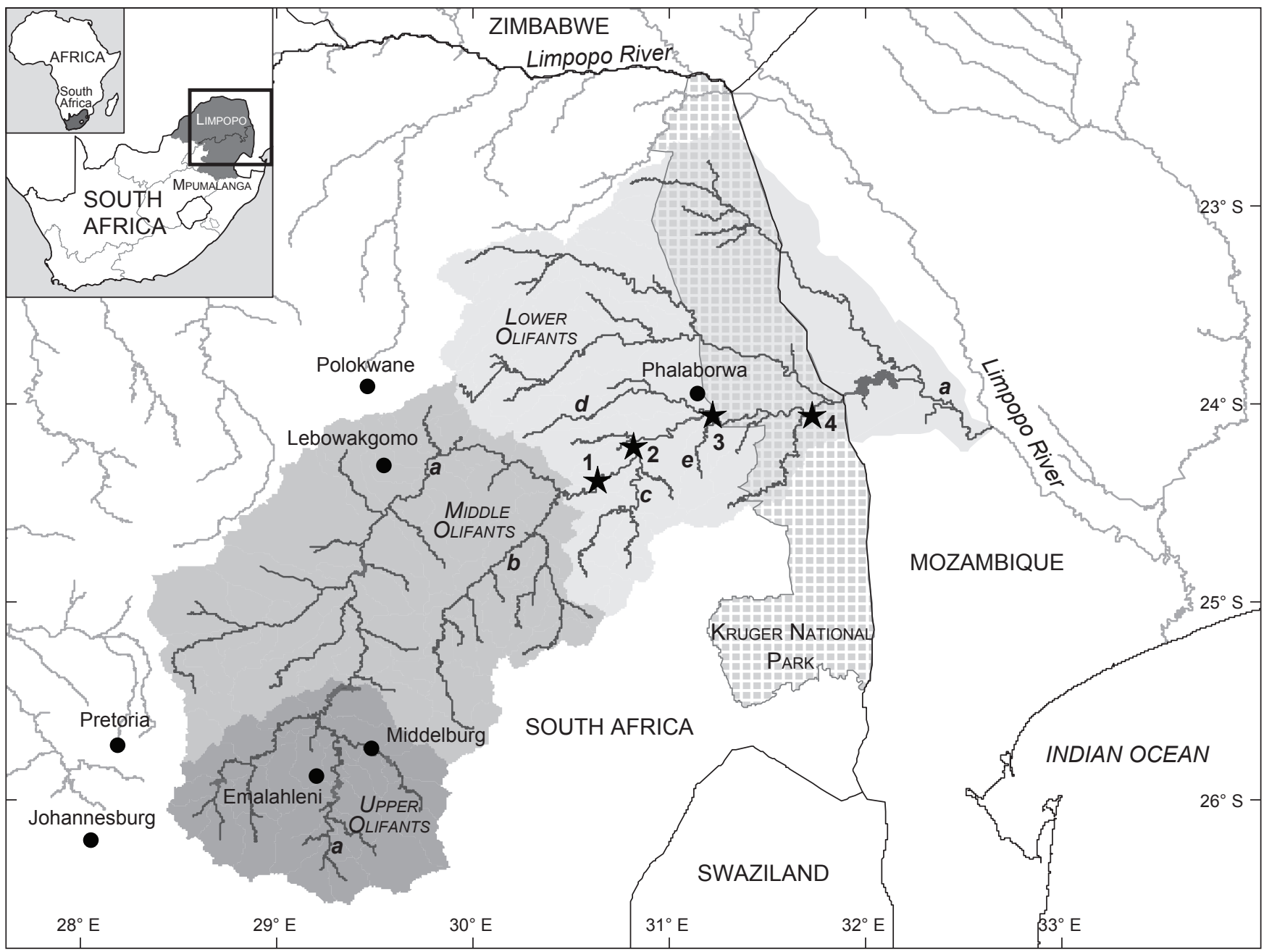

Figure 1: Map of the Olifants River system showing locations of major towns and tributaries. The Olifants River and its tributaries are: a) Olifants main stem, b) Steelpoort, c) Blyde, d) Selati and e) Klaserie. The main stem sample sites, represented by black stars, are: 1) Manoutsa, 2) Hippo Pools, 3) Mamba and 4) Balule

better (South African Government 2015) fish herpetofauna, instream habitat, biological assemblages and diatom communities must be in a moderately modified or better condition; periphyton must be in a condition that does not reflect eutrophic conditions, habitat requirements of species of special ecological importance, aquatic bird communities and local Hippopotamus population must be provided for to ensure viable and sustainable populations; and low and high flows must be suitable to maintain the river habitat and ecosystem condition. For water quality, sediment loads must be reduced so that sedimentation does not negatively impact on habitat state and toxicity levels must not pose a threat to the ecosystem and local users (South African Government 2015). The Southern African Development Community has established a protocol for shared watercourses (SADC 2000; Kistin et al. 2009), which requires states to ensure the judicious and coordinated utilisation of shared water systems (Kistin et al. 2009). Although water quality is not explicitly mentioned in the protocol (Ashton and Dabrowski 2011), the protocol requires that signatories ensure that their water use in a shared basin does not cause appreciable harm to a neighbouring country (SADC 2000; Kistin et al. 2009; Ashton and Dabrowski 2011).

Water quality and biomonitoring data have historically been collected in South Africa by the Department of Water Affairs and Forestry (DWAF) and its subsequent incarnations, at a number of river sampling sites in the Olifants River and its tributaries (Hill et al. 2001). However, the current monitoring effort is considered inadequate, because of the coverage of sites monitored, sampling frequency, the lag time between the sampling and the results of the analyses, the lack of monitoring of metals and the inability of the current monitoring programme to detect discrete pollution events (such as sewage overflow or chemical spills). Measures of river health (based on macroinvertebrate and fish communities and riparian vegetation) are only sampled every three years or longer, which means that trends cannot be determined at timescales for effective management actions (5-10 years) and pollution sources, or the consequences of pollution events, often cannot be determined. In 2009, the South African Observation Network (SAEON) initiated a long-term research programme at four sites within the 
Lowveld reaches of the Olifants River to identify major pollution events and quantify improvements in water quality and ecological conditions as the river flows through South Africa's premier protected area, the Kruger National Park. It was anticipated that the data produced would be of suitable resolution to quickly identify changes in the ecological condition of the river and lead to improved management of the lower Olifants River. This paper assesses the data collected over the first six years, to determine whether trends in the ecological condition of the river could be identified.

\section{Materials and methods}

\section{Sampling localities}

Four sites on the main stem of the Olifants River (Figure 1) were sampled from 2009 to 2015 every second month by a SAEON technician (TM): Manoutsa (S 24 22' 46”, E 30³9' $57^{\prime \prime)}$, Hippo Pools (S $24^{\circ} 11^{\prime} 50^{\prime \prime}$, E $\left.30^{\circ} 48^{\prime} 41^{\prime \prime}\right)$, Mamba (S $24^{\circ} 02^{\prime} 32^{\prime \prime}, \mathrm{E} 31^{\circ} 12^{\prime} 46^{\prime \prime}$ ) and Balule (S 240. 03' 08”, E $31^{\circ}$ $\left.43^{\prime} 47^{\prime \prime}\right)$. Manoutsa was selected to describe the water quality as the Olifants River enters the Lowveld, Hippo Pools the impact of the Blyde River and agricultural activities along the Olifants River, Mamba the impact of the Selati River before the Olifants River enters the Kruger National Park and Balule the change in water quality through the Kruger National Park.

Water quality, SASS and fish sampling

Sampling took place from 2009 to 2015. In situ water temperature, $\mathrm{pH}$, dissolved oxygen and electrical conductivity were recorded (Eutech Instruments Cyberscan PC 300 (2009-2013) and subsequently YSI Model 554 Data logger). Macroinvertebrates were collected using SASS kick sampling (Dickens and Graham 2002) from stones; vegetation; and gravel, sand and mud biotopes using a standard $1 \mathrm{~mm}$ mesh $300 \times 300 \mathrm{~mm}$ SASS net. Each biotope was sampled, the aquatic macroinvertebrates identified and scored in the field and returned to the river by an accredited SASS practitioner (TM) following Dickens and Graham (2002). Fish were collected using single pass electrofishing with a SAMUS backpack electrofisher (Model 760G), or Honda 220 V AC 2 kVa generator where the conductivity was too high. No block nets were used. Fish captured were stored in aerated containers, identified according to Skelton (2001), counted and returned to the river.

\section{Statistical analyses}

Boxplots were prepared to summarise the physico-chemical parameters by site. The Shapiro-Wilk normality test was used to test for normality of the variables, a significant result indicating that the variable was not normally distributed. The Shapiro-Wilk normality test returned a significant result for each water physico-chemical parameters therefore non-parametric tests were used. A Kruskal-Wallis test was used to evaluate whether the physico-chemical parameters varied between sites. Results were considered statistically significance at $p \leq 0.05$. Dunn tests (Dunn 1964) were used to determine the pairwise interactions that contributed to the significant result.

The site SASS score (all taxa recorded) and average score per taxon (ASPT) were calculated for each site visit. The ASPT was plotted against the SASS score and compared to biological bands (REFERENCE, GOOD, FAIR, POOR or SERIOUSLY OR CRITICALLY MODIFIED) of the ecological integrity using the composite values for the Lowveld aquatic ecoregion from Dallas (2007). Boxplots were prepared to summarise variations in the ASPT along the longitudinal profile of the Olifants River. The temporal variation in the ASPT was summarised in time series plots. The aforementioned statistical analyses were conducted using R 3.3.1 statistical software (R Development Core Team 2016).

Presence-absence data for the aquatic invertebrate taxa were used to evaluate variation in aquatic invertebrate communities. A resemblance matrix was constructed using the Sørensen index (Sørensen 1948), Bray-Curtis similarity equivalent for presence-absence data (Koleff et al. 2003) and a non-metric multidimensional scaling (NMDS) ordination plot (Clarke and Warwick 2001) prepared to visualise the data using the PRIMER E6 statistical software (Clarke and Gorley 2006).PERMDISP and PERMANOVA routines in the PERMANOVA+ extension to PRIMER E6 (Anderson et al. 2008) were used to determine whether the multivariate dispersion about the group centroid differed significantly between the sites and whether the position of the site centroids in multivariate space and/or the multivariate dispersion about the group centroids differed significantly between the sites (Anderson 2001). A SIMPER analysis (Clarke and Warwick 2001) was performed to determine the taxa contributing most to the differences between the sites using PRIMER E6.

The fish abundance data were summarised for each site and the number of species, number of fish and the Margalef diversity index (Clarke and Warwick 2001) calculated. The fish species recorded at each site were compared to the expected fish communities for each ecoregion from Angliss et al. (2005). To provide a metric for the fish communities, the intolerance to modifications in physico-chemical conditions sensu Kleynhans (2005) was used to calculate an average intolerance for each site (scale of 1 to 5 with the higher number indication the least tolerant species). A resemblance matrix was constructed from $\log (x+1)$ transformed annual abundance data using Bray-Curtis similarity and a NMDS ordination plot was prepared. In addition, PERMDISP and PERMANOVA analyses were performed to determine whether there were differences in the position of the centroids for each site and a SIMPER analysis conducted to determine the taxa contributing to similarity within and dissimilarities between sites.

\section{Results}

\section{Physico-chemical parameters}

The water physico-chemical parameters measured over six years are summarised in Figure 2. The conductivity, dissolved oxygen and oxygen saturation results were not significantly different between sites, with large variations within sites. The coefficient of variation for conductivity was approximately $30 \%$ for all sites, except Mamba, where it was $23 \%$. The dissolved oxygen concentration and percent saturation decreased from Manoutsa to Mamba but increased to Balule. The coefficient of variation was $<50 \%$ at all sites for both oxygen concentration and saturation. The $\mathrm{pH}$ was significantly different between sites $(p=$ 

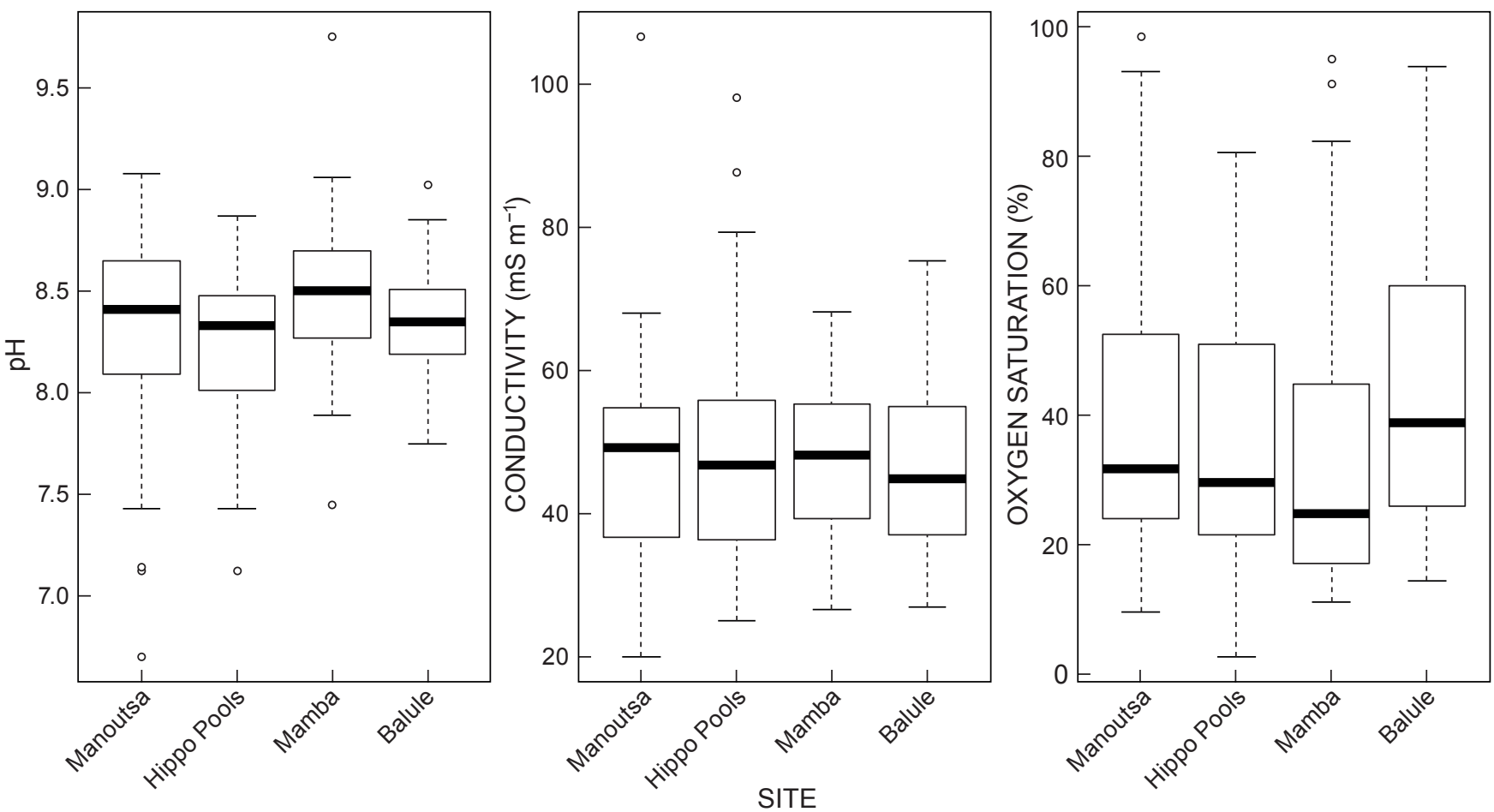

Figure 2: Boxplots summarising the physico-chemical parameters for the Lowveld reaches of the Olifants River between 2009 and 2015

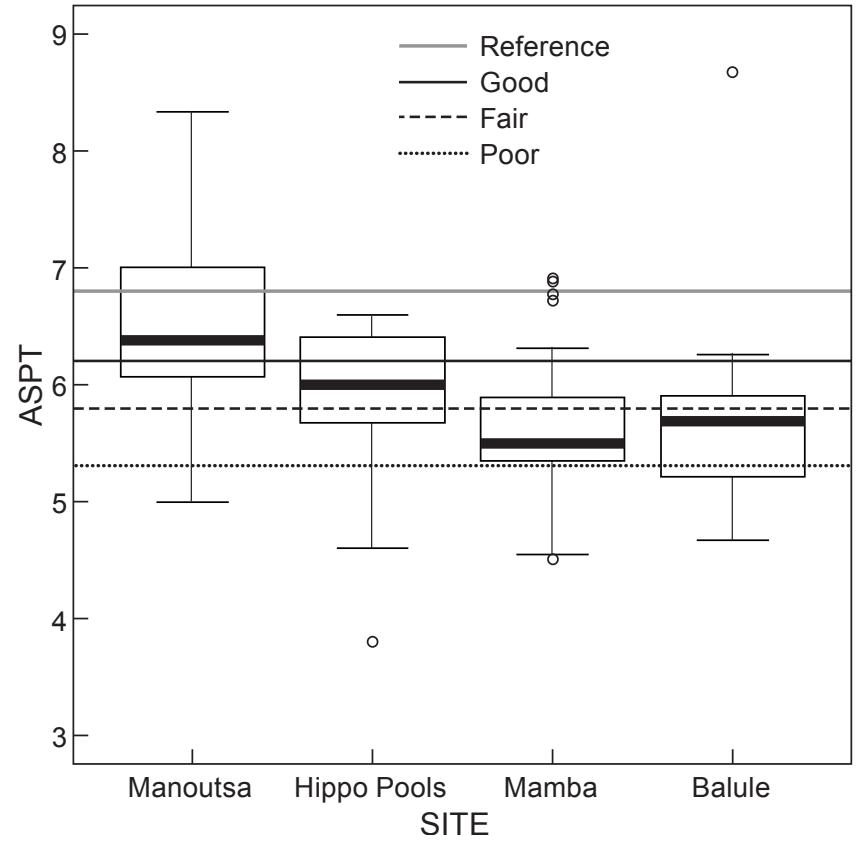

Figure 3: Boxplots summarising the average score per taxon (ASPT) for the Lowveld reaches of the Olifants River between 2009 and 2015. The site condition is indicated by various lines: above the solid grey line REFERENCE, above the solid black GOOD, above dashed FAIR, above dotted POOR and below the dotted line SERIOUSLY OR CRITICALLY MODIFIED condition
0.019), rising from 8.3 at Manoutsa to 8.5 at Mamba, before dropping to 8.3 at Balule. However the post hoc Dunn test revealed that the only significant pairwise difference was between Hippo Pools and Mamba $(p=0.011)$. Interestingly, the coefficient of variation (CV) in the $\mathrm{pH}$ decreased from $5 \%$ at Manoutsa to $3 \%$ at Balule, indicating lower variability lower in the catchment.

\section{Aquatic macroinvertebrates}

The average score per taxon (ASPT) appeared to decline along the Olifants main stem from Manoutsa to Balule (Figure 3), with statistically significant differences amongst sites $(p<0.001)$. The post hoc Dunn test confirmed statistically significant differences in ASPT between Manoutsa and Mamba and Manoutsa and Balule (both $p=0.002$ ). The average condition of the sites was GOOD at Manoutsa, FAIR at Hippo Pools and POOR at both Mamba and Balule (Figure 3). There was no strong correlation between the physico-chemical parameters and APST (Pearson $\mathrm{R}<0.3$ for all parameters). Time series data suggest a declining trend in ASPT for some sites (Figure 4), but this was not supported statistically (separate linear regressions for each site all had $p>0.05$ ). A list of the invertebrate taxa recorded by site is included in Table S1 (Supplementary Material).

Although no clear separation was evident between the sites in the MDS plot (Figure 5), the PERMDISP analysis returned a non-significant result $(p=0.371)$ and the PERMANOVA a significant result $(p=0.001)$ indicating a significant difference in the position of the site centroids. A pair-wise PERMANOVA confirmed that the position of each centroid was unique. The SIMPER analysis showed that the similarity within the sites was between 40 and $50 \%$ 

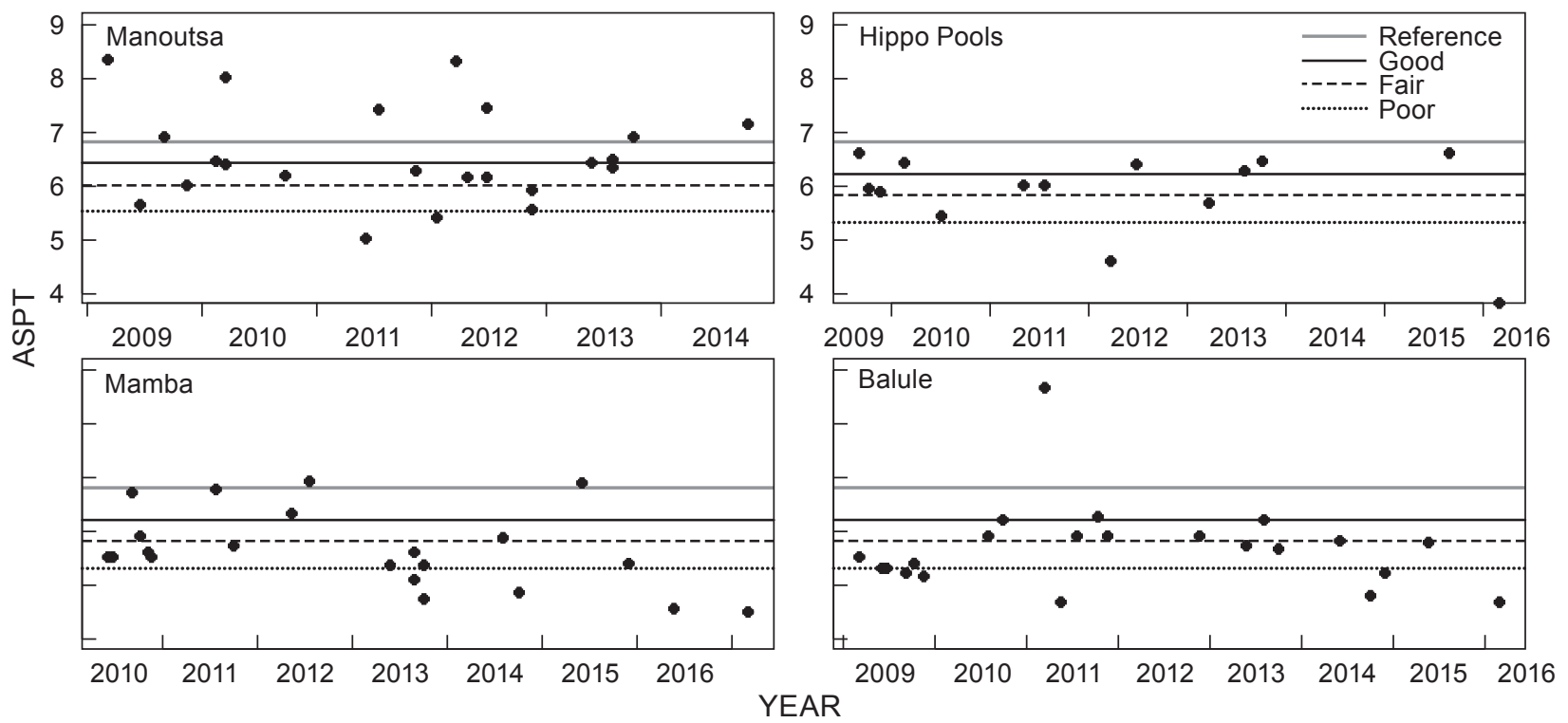

Figure 4: Time series plots summarising the average score per taxon (ASPT) calculated from the SASS scores between 2009 and 2015. The site condition is indicated by various lines: above the solid grey line REFERENCE, above the solid black GOOD, above the dashed line FAIR, above dotted line POOR and below the dotted line line SERIOUSLY OR CRITICALLY MODIFIED condition

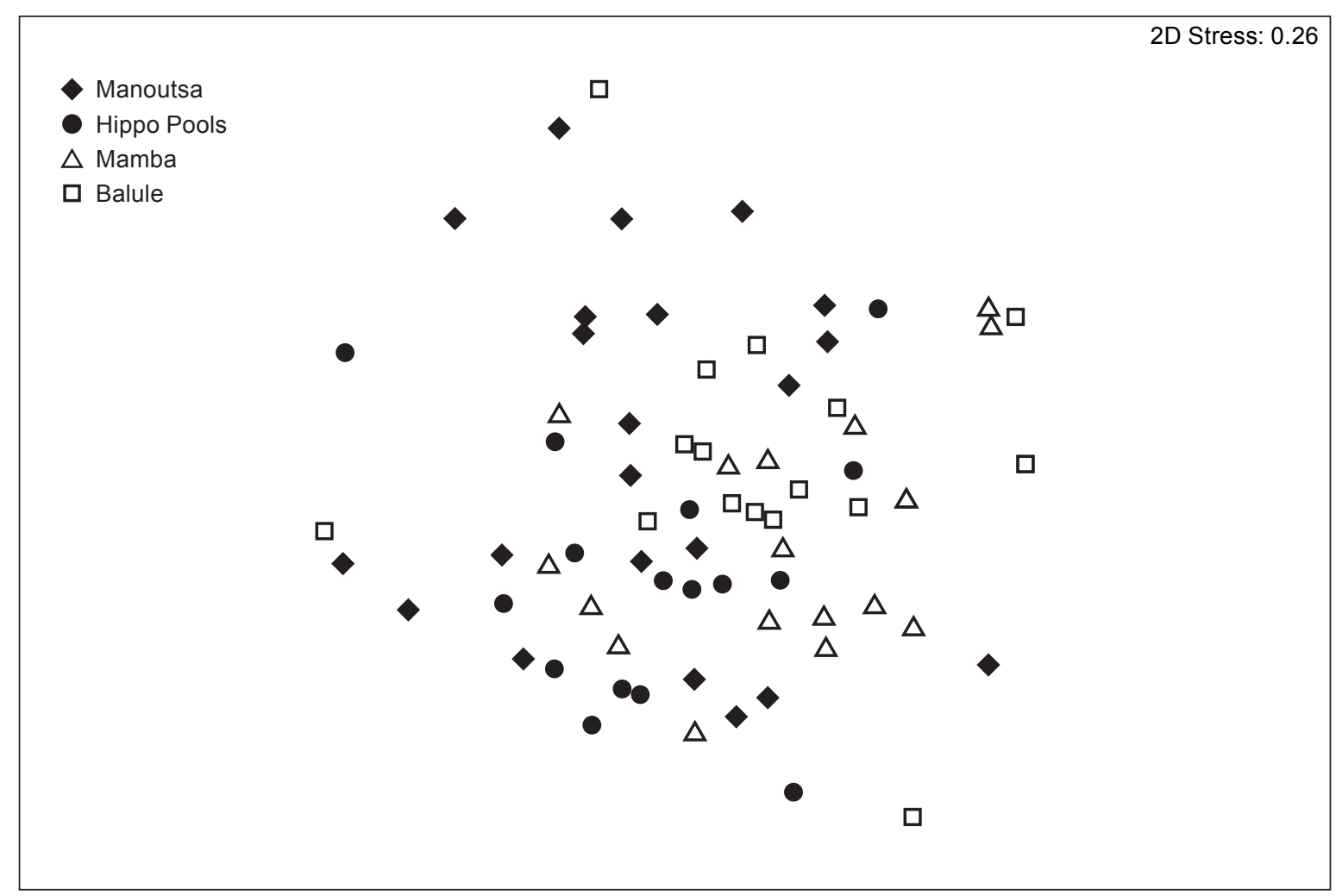

Figure 5: Non-metric multidimensional scaling plot of invertebrate communities at four sites on the Olifants River between 2009 and 2015. Presence-absence data were analysed using the Sorensen index. Open symbols are used for sites within the Kruger National Park (Mamba $\Delta$ and Balule $\square$ ) and solid symbols for sites upstream of the Kruger National Park (Manoutsa $\bullet$ and Hippo Pools •) 
(Manoutsa 44\%, Hippo Pools 49\%, Mamba 51\% and Balule $48 \%$ ) and the dissimilarity between the sites approximately 55\% (Manoutsa-Hippo Pools 56\%, Manoutsa-Mamba 58\%, Manoutsa-Balule 57\%, Hippo Pools-Mamba 53\%, Hippo Pools-Balule 56\% and Mamba-Balule 53\%). When the sites within the Kruger National Park were compared to those outside the park, some separation emerged (Figure 5). Again, the PERMDISP analysis returned a non-significant result $(p=0.272)$ and the PERMANOVA returned a significant result $(p=0.001)$ indicating that there was a significant difference in the position of the group centroids. Sites within the Kruger National Park had a $48 \%$ similarity with approximately $50 \%$ of the group similarity, as a result of Thiaridae $(10 \%)$, Gomphidae $(9 \%)$, Leptophlebiidae $(9 \%)$, Libellulidae (8\%), Chironomidae $(6 \%)$, Simuliidae $(5 \%)$ and Veliidae (5\%). Sites outside the Kruger National Park had $45 \%$ similarity with approximately $50 \%$ of the group similarity, as a result of Libellulidae (14\%), Gomphidae (14\%), Baetidae $>2$ species $(9 \%)$, Tricorythidae $(7 \%)$,

Table 1: Summary of fish diversity at four sites on the Olifants River

\begin{tabular}{lccc}
\hline Site & $\begin{array}{c}\text { Number of } \\
\text { species }\end{array}$ & $\begin{array}{c}\text { Total number } \\
\text { of fish }\end{array}$ & $\begin{array}{c}\text { Margalef } \\
\text { diversity }\end{array}$ \\
\hline Manoutsa & 18 & 2604 & 2.162 \\
Hippo Pool & 10 & 1825 & 1.199 \\
Mamba & 11 & 1261 & 1.401 \\
Balule & 18 & 2782 & 2.144 \\
\hline
\end{tabular}

Tabanidae (6\%) and Simuliidae (5\%). The dissimilarity between the groups was $56 \%$ with more than $50 \%$ of the dissimilarity, as a result of Thiaridae, Corbiculidae, Tricorythidae, Veliidae, Naucoridae, Ceratopogonidae, Leptophlebiidae, Elmidae, Heptageniidae, Coenogrionidae, Leptoceridae, Tabanidae, Hydropsychidae >2 species, Simuliidae and Baetidae 2 species.

Fish

A summary of the number of species and selected diversity indicators of the fish captured sites is presented in Table 1. The Margalef diversity index was highest at Manoutsa and lowest at Hippo Pools, after which the value rose through Mamba to Balule, where it approached the Manoutsa value. The average fish intolerance was highest at Manoutsa and Hippo Pools (both 2.8), dropping to 2.4 at Mamba before recovering to 2.6 at Balule. This indicates that Manoutsa and Hippo Pools had a higher proportion of less tolerant fish species, even though the diversity and number of species recorded at these sites varied considerably. Mamba had the lowest proportion of species intolerant to modifications in physico-chemical conditions sensu Kleynhans (2005). An increase in the diversity of the fish community between Mamba and Balule was evident from an increase in all fish metrics calculated. Less than $50 \%$ of the 36 species expected at each site were captured over the 6 years; Manoutsa $50 \%$ of expected species, Hippo Pools 28\%, Mamba $27 \%$ and Balule $47 \%$. This might be an artefact of the sampling technique used

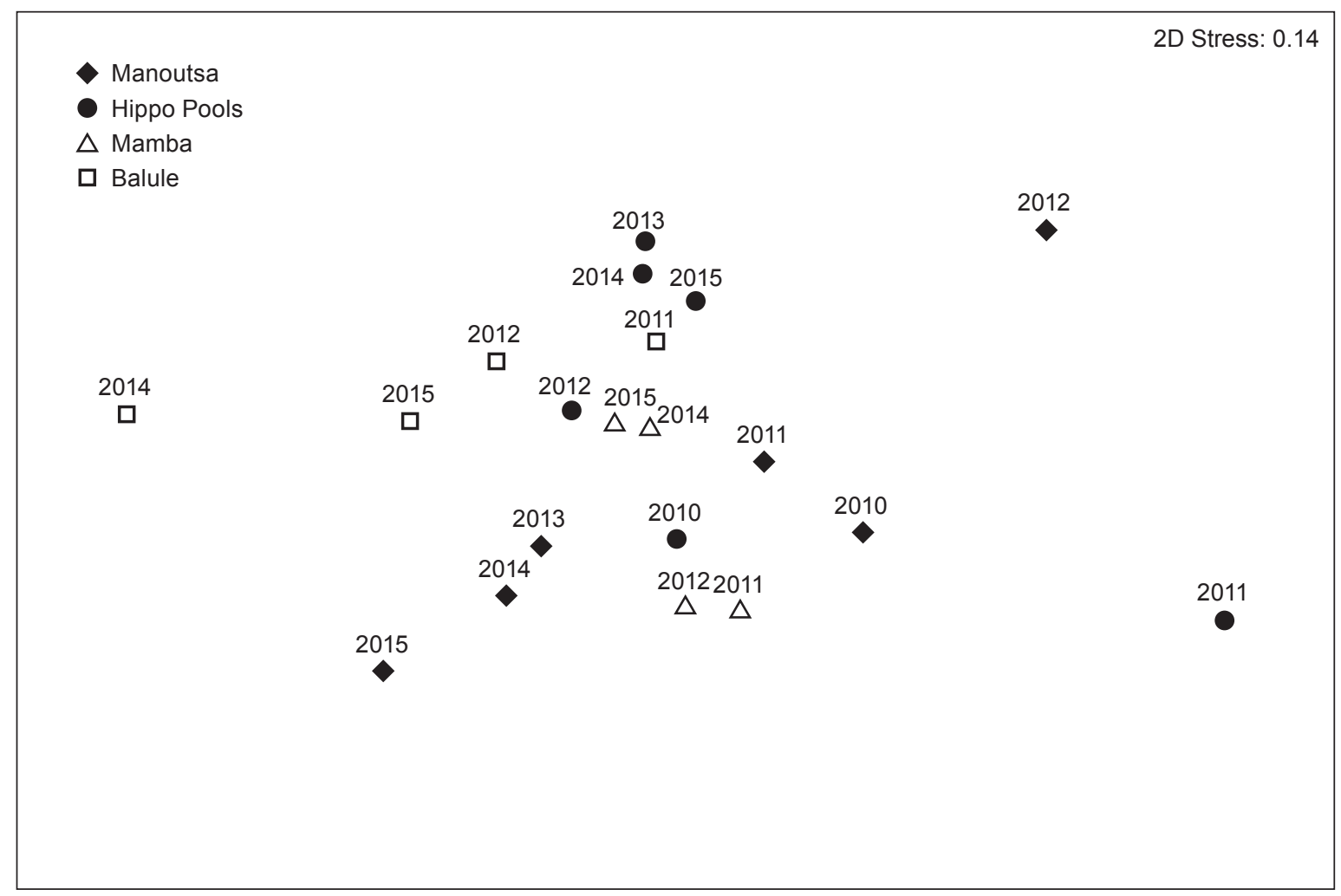

Figure 6: Non-metric multidimensional scaling plot of fish communities at Manoutsa $(\triangleleft)$, Hippo Pools $(\bullet)$, Mamba $(\Delta)$ and Balule $(\square)$ on the Olifants River from 2009 to 2015 based on annual data, log $(x+1)$ transformed and Bray-Curtis similarity 
and/or the heterogeneity of habitat available at each site. A list of fish species recorded is included in Table S2 (Supplementary Material).

The NMDS plot of fish communities indicated some separation between the sites (Figure 6) but both the PERMDISP analysis and the PERMANOVA returned a non-significant result ( $p=0.638$ and $p=0.163$, respectively), indicating no significant difference between the species composition and abundances between sites. The SIMPER analysis showed that the similarity within the sites varied a great deal for the main stem (Manoutsa 50\%, Hippo Pools $60 \%$, Mamba $70 \%$ and Balule $57 \%$ ). The similarity of the fish community between the sites can be attributed to Chiloglanis paratus, Labeobarbus marequensis, Labeo cylindircus, Clarias gariepinus and Labeo molybdenus, all of which were frequently collected at each site.

\section{Discussion}

\section{Physico-chemical parameters}

The physico-chemical parameters measured, with the exception of $\mathrm{pH}$ between Hippo Pools and Mamba, showed no significant differences between the sites. This difference in $\mathrm{pH}$ might result from the alkaline geology of the Lowveld reaches, the low $\mathrm{pH}$ of the Blyde River and the high $\mathrm{pH}$ of the Selati River (Marr et al. 2017). Considering that there is no similar result for conductivity, which was relatively higher in the Selati River, the alkaline geology appears a more plausible explanation. Furthermore, the flow of the main stem Olifants River is more than ten times that of both tributaries combined resulting in the physicochemical parameters of the waters downstream of the confluence tending towards those of the main stem unless the tributary carries an exceptionally high pollution load. No long-term trend was evident for any of the physicochemical parameters over 6 years although large seasonal fluctuations, evident from the larger coefficients of variation of the parameters, might have confounded any trend over the study period. The timescale of the study might not have been sufficient to detect long-term trends, or perhaps a broader set of parameters needs to be monitored. Alternatively, there might simply have been no significant change in the water chemistry parameters measured over the duration of the study. There has been an observable increase in filamentous algae at the two lower study sites that might be indicative of increasing eutrophication. Although it is possible that this has occurred without significant changes in $\mathrm{pH}$ or conductivity, it seems unlikely that dissolved oxygen would not have been affected. More frequent sampling of dissolved oxygen might therefore have yielded different results.

The physico-chemical parameters selected, as well as their sampling frequency, appear to have been unsuitable for the early detection of pollution events in the study area. The major problems in the lower Olifants River include reduced flows, massive floods, metal pollution, elevated nutrients and pesticides (Heath et al. 2010; Ashton and Dabrowski 2011), all of which currently impact the river health and habitat heterogeneity. A better assessment of the state and trends of the ecological health of the river could require expansion of the parameters recorded to include chlorophyll a, cyanobacteria, sulphate, nutrients (nitrite, nitrate, ammonium, ammonia, orthophosphate), selected metals (e.g. aluminium, copper, chromium, manganese and zinc) and pathogens, e.g. E. coli. Budget limitations require that the variables frequently measured be carefully chosen to be sufficient to detect long-term trends in the ecological condition of the river. However, critical parameters missing from the current water monitoring include aluminium and sulphate (monitoring of acid mine drainage), nutrients (monitor of eutrophication) and selected toxic metals and metalloids e.g. antimony, arsenic, chromium, copper and lead. Furthermore, real-time monitoring of conductivity and possibly $\mathrm{pH}$, at selected gauging weirs would provide a better basis to identify the occurrence and source of pollution events. Such data can be made available remotely with preselected thresholds identified to trigger alarms that notify the relevant managers of an exception thus providing an early warning for rapid response.

\section{Aquatic macroinvertebrates}

The SASS5 assessment of aquatic macroinvertebrates indicated a decline in river health from Manoutsa to Balule, with the decreasing ASPT along the lower Olifants River confirmed by statistically significant differences between Manoutsa and the two Kruger National Park sites: Mamba and Balule. There was some evidence of an improvement in river health as it flows through the Kruger National Park but the increase in ASPT between Mamba and Balule was not statistically significant. The apparent deterioration between Hippo Pools and Mamba might largely result form pollution emanating from the Selati River (Marr et al. 2017). The SASS assessment therefore identified changes in the river health not detected by the physico-chemical parameters. However, the lowest ASPT values at Mamba were consistent with that site having the highest $\mathrm{pH}$ and lowest $\mathrm{O}_{2}$ saturation values, suggesting that site is the most impacted by pollution.

The multivariate analysis of invertebrate communities showed that each site had a distinct biotic community, as reported by Schael and King (2005) for the Western Cape. This could be a combined result of the habitat template available at each site and the impact of inputs from the tributaries. The SASS scores were, however, highly variable with the ecological condition varying from REFERENCE to POOR between visits. Site heterogeneity and seasonality might play a role, particularly late in the dry season, where certain biotopes might not be present. However, the large variation in ASPT might indicate the high resilience of macroinvertebrate communities, with rapid rebounding after known catastrophic events. For example, ASPT values rapidly recovered to preflood values following a severe flood in January 2012 (see Figure 4). Consequently, the ability of SASS biomonitoring to identify deleterious events might be limited, as a result of the rapid recolonisation from neighbouring reaches or downstream drift. As with the physico-chemical parameters, no long-term trend in ASPT could be identified for the sites.

\section{Fish}

Although the study was not designed as a biodiversity assessment, it is concerning that less than $50 \%$ of the 
expected fish species were recorded at each site over the six years of the monitoring programme. A number of species preferring deep pools, such as Anguilla eels, Labeo congoro, Labeo ruddi, Hydrocynus vittatus, mormyrids Marcusenius pongolensis and Petrocephalus wesselsi and Schilbe intermedius were not collected. These species constitute approximately $25 \%$ of the expected species and their absences suggest that inadequate sampling of deep pools might be the main reason for the low species richness recorded. Considering the challenges posed by crocodiles and hippos to sampling fish in the Lowveld, pools are likely to be undersampled by electrofishing, which was the sole fish sampling technique used. Alternatively, these species might have been lost from the sites studied, perhaps as a result of the loss of their habitat because of the increasing severity of recent floods.

The fish data showed greater diversity and the occurrence of more species sensitive to pollution upstream of the Kruger National Park. This leads to the conclusion that the Olifants River in the Kruger National Park might not currently be serving as a refuge for freshwater fishes, as would be expected for such a large and well-established protected area. Again, pollution inputs from the Selati River just upstream of the park might be having a very significant impact on the fish abundance and diversity in the protected area. Further, the fish population in the Kruger National Park might not have recovered from past pollution events or recruitment from refuges offered by the tributaries in the protected area might be insufficient. The increase in the number of fish species recorded at Balule might be as a result of recruitment from the Letaba River, a major tributary that confluences with the Olifants downstream of Balule, which does not experience the pollution load of the Olifants River. The Letaba River has been identified as an important refuge for fish in the Kruger National Park (Driver et al. 2011), although this refuge maybe threatened by proposals for the construction of a further dam on the Groot Letaba River (South African Government 2012). Suitable environmental releases from the new dam will be required to ensure adequate recruitment of fish species in the Letaba River.

\section{Conclusions}

This analysis of the first six years of the long-term study of the river condition of the Olifants River has shown that, despite some deficiencies, the study is beginning to raise some important questions regarding the long-term health of the Olifants River and the functionality of the Kruger National Park reaches as protected areas for fish and aquatic macroinvertebrates. Although, the physicochemical parameters measured need to be expanded in order to detect the diverse array of contaminants known to be entering the lower reaches of the river, which include eutrophication, metals and major anions (particularly sulphate). The Selati River was identified as the most likely cause of the poor conditions of sites the lower Olifants River within the Kruger National Park; see Marr et al. (2017). The monitoring of aquatic macroinvertebrates using the SASS 5 methodology was able to identify that the sites above the confluence with the Selati River are in a better condition than those below. The fish monitoring recorded less than $50 \%$ of the fish species expected and the fish sampling method should be revised to allow effective sampling of pools. The fish diversity and abundance found for the two sites in the Kruger National Park is a concern and the status of refuges in tributaries within the park need to be investigated.

Acknowledgements - We thank Prof Paul Fouché and Dr Wynand Vlok for their contributions to the design of the project and training of the technician (TM). The research reported here was fully funded by the South African Environmental Observation Network (SAEON). The handling editor and two anonymous reviewers are thanked for their contributions, which that significantly improved this manuscript.

\section{References}

Anderson MJ. 2001. Permutation tests for univariate or multivariate analysis of variance and regression. Canadian Journal of Fisheries and Aquatic Sciences 58: 626-639.

Anderson MJ, Gorley RN, Clarke KR. 2008. PERMANOVA+ for PRIMER: Guide to Software and Statistical Methods. PRIMER-E: Plymouth Marine Laboratory, Plymouth, UK. 214 pp.

Angliss MK, Rodgers SSM, Fouche PSO, Wiggins L, Vlok W, Malungani $\mathrm{M}$ et al. 2005. A biomonitoring survey of the Olifants River catchment falling within Limpopo Province: Field survey of 2004. River Health Programme. 37 pp.

Ashton PJ, Dabrowski M. 2011. An overview of water quality and the causes of poor water quality in the Olifants River Catchment. WRC Project No. K8/887. Water Research Commission, Pretoria. 189 pp.

Bunn SE. 2016. Grand challenge for the future of freshwater ecosystems. Frontiers in Environmental Science 4: 1-21.

Clarke KR, Gorley RN. 2006. PRIMER v6: User Manual/Tutorial. PRIMER-E: Plymouth Marine Laboratory, Plymouth, UK. 190 pp.

Clarke KR, Warwick RM. 2001. Change in Marine Communities: An Approach to Statistical Analysis and Interpretation, 2nd edition. PRIMER-E: Plymouth Marine Laboratory, Plymouth, UK. 190 pp.

Dallas HF. 2007. River Health Programme: South African Scoring System (SASS) Data Interpretation Guidelines. Institute of Natural Resources and Department of Water Affairs and Forestry, Pretoria. $85 \mathrm{pp}$.

de Villiers S, Mkwelo ST. 2009. Has the monitoring failed the Olifants River, Mpumalanga? Water SA 35: 671-676.

Dickens CWS, Graham PM. 2002. The South African Scoring System (SASS) Version 5 rapid bioassessment method for rivers. African Journal of Aquatic Science 27: 1-10.

Driver A, Nel JL, Snaddon K, Murray K, Roux DJ, Hill L, Swartz ER, Manuel J, Funke N. 2011. Implementation manual for Freshwater Ecosystem Priority Areas. Water Research Commission. WRC Report No. 1801/1/11, Pretoria. 119 pp.

Dunn OJ. 1964. Multiple comparisons using rank sums. Technometrics 6: 241-252.

Heath R, Coleman T, Engelbrecht J. 2010. Water quality overview and literature review of the ecology of the Olifants River. WRC Report No. TT452/10. Water Research Commission, Pretoria, South Africa. $51 \mathrm{pp}$.

Hill L, Vos P, Moolman J, Silberbauer M. 2001. Inventory of River Health Programme monitoring sites on the Olifants, Sabie and Crocodile Rivers. WRC Report No 850/2/01. Water Research Commission, Pretoria. $418 \mathrm{pp}$.

Jooste A, Marr SM, Addo-Bediako A, Luus-Powell WJ. 2015. Sharptooth catfish shows its metal: a case study of metal contamination at two impoundments in the Olifants River, Limpopo river system, South Africa. Ecotoxicology and Environmental Safety 112: 96-104.

Kistin EJ, Ashton PJ, Earle A, Malzbender D, Patrick MJ, Turton 
AR. 2009. An overview of the content and historical context of the international freshwater agreements that South Africa has entered into with neighbouring countries. International Environmental Agreements: Politics, Law and Economics 9: 1-21.

Kleynhans CJ. 2005. Module D: Fish Response Assessment Index (FRAI). Department of Water Affairs, Pretoria. 80 pp.

Kleynhans CJ, Thirion C, Moolman J. 2005. A Level I River Ecoregion classification System for South Africa, Lesotho and Swaziland. Report No. N/0000/00/REQ0104. Resource Quality Services, Department of Water Affairs and Forestry, Pretoria, South Africa. $117 \mathrm{pp}$.

Koleff P, Gaston KJ, Lennon JJ. 2003. Measuring beta diversity for presence-absence data. Journal of Animal Ecology 72: 367-382.

Marr SM, Mohlala TD, Swemmer A. 2017. The ecological integrity of the lower Olifants River, Limpopo province, South Africa: 2009-2015 - Part B: Tributaries of the Olifants River catchment. African Journal of Aquatic Science 42. 181-190.

Nel JL, Roux DJ, Maree G, Kleynhans CJ, Moolman J, Reyers B, Rouget M, Cowling RM. 2007. Rivers in peril inside and outside protected areas: a systematic approach to conservation assessment of river ecosystems. Diversity and Distributions 13: 341-352.

R Development Core Team. 2016. R: A Language and Environment for Statistical Computing. R Foundation for Statistical Computing, Vienna, Austria, http://www.R-project.org. [accessed 1 October 2016].
SADC. 2000. Revised protocol on shared watercourses in the Southern African Development Community. Southern African Development Community, Windhoek. 20 pp.

Schael DM, King JM. 2005. Western Cape river and catchment signatures. WRC Report no. 1303/1/05. Water Research Commission, Pretoria. 154 pp.

Skelton PH. 2001. A complete guide to the freshwater fishes of Southern Africa. Struik Publishers, Cape Town, South Africa. 395 pp.

Sørensen TA. 1948. A method of establishing groups of equal amplitude in plant sociology based on similarity of species content, and its application to analyses of the vegetation on Danish commons. Kongelige Danske Videnskabernes Selskabs Biologiske Skrifter 5: 1-34.

South African Government. 2012. Notice 1051 of 2012. Government Gazette 35988: 59-66.

South African Government. 2015. National Water Act No. 36 of 1998 Proposed Classes and Quality Objectives of Water Resources for the Olifants Catchment. Government Gazette 39004: 1-57.

Vörösmarty CJ, Mclntyre PB, Gessner MO, Dudgeon D, Prusevich A, Green P et al. 2010. Global threats to human water security and river biodiversity. NATURE 467: 555-561. 